\title{
刺激条件の違いが手固有筋の皮膚反射に及ぼす影響
}

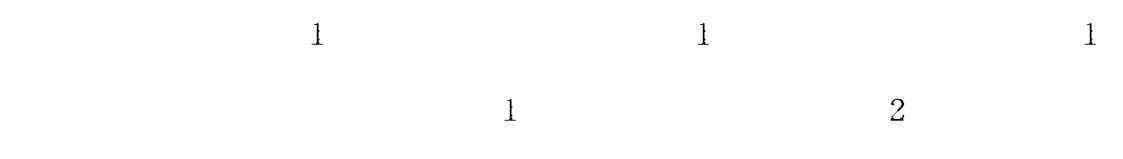

\section{EFFECTS OF ALTERING PARAMETERS FOR ELECTRICAL STIMULATION ON CUTANEOUS REFLEXES IN HUMAN INTRINSIC HAND MUSCLE}

\author{
TSUYOSHI NAKAJIMA, TAKASHI ENDOH, MASANORI SAKAMOTO, \\ TOSHIKI TAZOE and TOMOYOSHI KOMIYAMA
}

\begin{abstract}
The present study investigated an effective method of eliciting medium and long latency cutaneous reflexes in normal human subjects. The effect of changes in stimulus conditions (number of pulse train, duration of electrical pulse and inter-stimulus interval) on cutaneous reflexes in the first dorsal interosseous muscle (FDI) following non-noxious electrical stimulation to the hand digits (digit 1; D1, digit 2; D2 and digit 5; D5) were investigated in seven healthy volunteers. Cutaneous reflexes were elicited while the subjects performed isolated isometric contraction of FDI (D2 abduction). Under all experimental conditions, the level of muscle contraction was set at $10 \%$ of the maximal EMG amplitude, which was determined during maximal voluntary contraction. Intensity of the electrical stimulation was set at 2.0 times the perceptual threshold under all experimental conditions.

Although the amplitude of E2 (excitatory response, peak latency $\sim 60 \sim 90 \mathrm{~ms}$ ) was independent of the number of pulses ( $1,2,3$, and 5 pulses, pulse frequency at $333 \mathrm{~Hz}$ ), that of I 1 (inhibitory response, $\sim 45 \sim 60 \mathrm{~ms}$ ), I 2 (inhibitory response, $\sim 90 \sim 120 \mathrm{~ms}$ ) and E3 (excitatory response, $\sim 120 \sim 180 \mathrm{~ms})$ was significantly increased depending on the number of pulses $(\mathrm{p}<0.001)$. Amplitudes of E2 and I 2 were significantly affected by the digit stimulated $(p<0.01)$. For all four components of the cutaneous reflexes, there were no significant differences in magnitude even by alternating both the inter-stimulus interval (fixed at 1,2 and $3 \mathrm{~Hz}$ and random between at 0.7 and $2 \mathrm{~Hz})$ and the duration $(0.1,0.5$ and $1 \mathrm{~ms})$ of the electrical stimulation.

These findings suggest that the susceptibility of responsible interneurons impinging on each reflex pathway to temporal summation of the test impulse differs depending on the digit stimulated. It is also likely that almost the same population of the cutaneous afferent fibers were activated by test stimulation with different durations as far as the same stimulus intensity was utilized. As a practical application, double or more pulses up to $3 \mathrm{~Hz}$ without causing pain is recommended to effectively evoke medium and long latency cutaneous reflexes in FDI, which would reduce possible effects arising from fatigue.
\end{abstract}

(Jpn. J. Phys. Fitness Sports Med. 2005, $54: 315$ - 324)

key word: Cutaneous reflexes, number of stimulus, stimulus duration, inter-stimulus interval, habituation

\section{I．序論}

手指の巧緻な運動は, 他の哺乳動物には見られな いヒト特有のものである .この巧緻性の背景には大 脳皮質運動野による手指筋運動ニューロンの支配の
強さや筋や皮膚感覚受容器を介した反射経路の発達 があるものと考えられる ${ }^{1-3)}$. 特に，低閾値の皮 膚感覚受容器を介した反射(皮膚反射)は物体把握時 の素早いフィードバック制御に重要な役割を果たす と考えられている4).
1) 東京学芸大学大学院連合学校教育学研究科 干263-5822 千葉市稻毛区弥生町1-33

2)千葉大学教育学部

干263-5822 千葉市稲毛区弥生町1-33
United Graduate School of Education, Tokyo Gakugei University, 1-33, Yayoicho, Inage-ku, Chiba City, Chiba, 263-5822 Department of Health and Sports Sciences, Chiba University, 1-33, Yayoicho, Inage-ku, Chiba City, Chiba, 263-5822 
ヒトでは手指皮膚神経に対する低閾值電気刺激に より，手固有筋から潜時の異なる多相性の反射効果 を誘発することが可能であり，各皮膚反射成分は独 立した反射経路を持つことが示唆されている ${ }^{5,6)}$. Jenner and Stephens ${ }^{7}$ ) は, 短潜時促通成分 (潜時約 30 $\mathrm{ms}, \mathrm{E} 1$ )および短潜時抑制成分 (潜時約 $40 \mathrm{~ms}, \mathrm{I}$ 1) は脊䯣由来の寡シナプス性反射反応であること，ま た中潜時促通成分 (潜時約 $60 \mathrm{~ms} ， \mathrm{E} 2$ ) は皮質経由の 反射であることを明らかにしている．さらに，E2 以上の潜時を有する抑制 ( $\mathrm{I} 2$, 潜時 $90 \mathrm{~ms}$ )および促 通成分 (E 3，潜時約 $120 \mathrm{~ms}$ ) も，皮質経由の反射で ある可能性が高( ${ }^{3 \sim 7)}$. 近年，物体把握や手指の 連続タッピング等の機能的な運動課題遂行時に得ら れた実験結果から，皮膚反射の機能的な意義が明ら

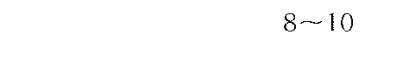

皮膚反射の機能的意義を検討する上で，皮膚反射 を誘発するための標準的刺激パラメータ，すなわち 刺激強度, 刺激パルス数, 刺激時間幅, 刺激間隔等 の確立は重要である .一般的に, 刺激強度に依存し て反射振幅は増大することが報告されているが 5 , 11,12)，E２より潜時の長い反射成分に関しては不 明な点も多い、下肢筋群の皮膚反射を対象とした 先行研究では, 標的介在ニューロンに対する時間的 加重効果を高める目的で, 刺激時間幅 $1 \mathrm{~ms}$ の矩形 波を 3 から 5 発 $\left(300 \mathrm{~Hz}\right.$ 程度)与えている ${ }^{12 \sim 14)}$. 方，手指筋群を対象とした研究では 0.1 もしくは $0.2 \mathrm{~ms}$ 幅, 単発刺激が多く用いられている ${ }^{7 \sim 11)}$. しかしながら，刺激パルス数や刺激時間幅の変化が 皮膚反射の振幅に及ぼす影響について系統的に調べ た研究は行われていない .これらの刺激条件以外に も刺激間隔(固定もしくはランダム刺激)は反射の振 幅に影響を及ぼす重要な因子であることが知られて (る ${ }^{15,16)}$. 高頻度刺激を用いた場合，いわゆる'反 射順応現象’を引き起こすことが知られており，皮 質経由と考えられる長潜時伸張反射が減弱すること が報告されている ${ }^{15)}$. 近年，この要因をできるだ け除外するためにランダム刺激法を用いることがあ るが ${ }^{14 \sim 17)}$, 手指筋群の皮膚反射に関して刺激間隔 の違いが皮膚反射に及ぼす影響については不明な点 が多い.

本研究の目的は, 刺激条件, 特に刺激パルス数, 刺激時間幅ならびに刺激間隔に着目して，手指皮膚 神経由来の皮膚反射の各成分がどのような影響を受
けるのかについて明らかにすることである．また， 皮膚反射は刺激部位依存的な変化を示すことが知ら れている ${ }^{18,19)}$ 。乥こで，各手指由来の皮膚反射に 関しても刺激条件による変化動態についても検討を 加えた .

$$
\text { II. 方法 }
$$

\section{A. 被験者}

被験者は, 神経学的疾患のない健康な成人男性 7 名(20４5歳)であった．実験手順と方法は所属施設 における倫理委員会の承諾を得て行った．关の後， 被験者には事前に実験の目的と方法を十分に説明 し，実験参加の同意を得た後に実験を行った．

\section{B．筋電図記録}

筋電図 $(E M G)$ は, 右第一背側骨間筋(FDI)の筋腹 上に約 $1 \mathrm{~cm}$ の電極間距離に置いた一対の表面電極 (直径 $10 \mathrm{~mm}$ )により，双極表面誘導法にて，時定 数 0.01 秒, 高域遮断周波数 $1 \mathrm{kHz}$ により生体アン プシステム(日本電気三栄，1253A)で増幅 (x1000) することにより得た . 記録電極は, 銀血電極(日本 光電, NT $-511 G)$ を用い, 弚の貼付に先立ち，電極 設置部位の皮膚をサンドペーパーで軽く削り，消毒 用エタノールで拭くことにより電極間抵抗を $10 \mathrm{k} \Omega$ 以下にした 。

\section{C. 電気刺激}

第 1 指(D1)，第 2 指(D2) および第 5 指(D5)の 近位指節間関節に一対のリング電極(陽極；遠位部， 陰極；近位部)を設置し，指皮膚神経を電気刺激し た(日本光電，SEN-7203). 用いた電気刺激は全て 矩形波であった .

刺激条件 1 : 刺激パルス数として $1 ， 2 ， 3$ およ び 5 発を用いた .この実験では，刺激時間幅は 1 $\mathrm{ms}$ を用いた。 2 発以上のパルスを用いた場合のパ ルス頻度は $333 \mathrm{~Hz}$ であった .

刺激条件 2 : 刺激時間幅として0.1，0.5および 1 ms を用い，皮膚反射を誘発した。この実験では， 2 発刺激(パルス頻度 $333 \mathrm{~Hz}$ )を用いた .

刺激条件 3 : 刺激間隔として固定 $(1 ， 2 ， 3 \mathrm{~Hz})$ およびランダム $(0.7 \sim 2 \mathrm{~Hz})$ を用いた .この実験で は, 刺激時間幅は $1 \mathrm{~ms}, 2$ 発刺激(パルス頻度 333 $\mathrm{Hz}$ )を用いた . 
各条件ともに電気刺激回数は 100 回であった . 刺 激強度は各条件ともに感覚閾值(PT)の 2 倍で統一 した .この刺激強度は痛み感覚をともなわないこと を全被験者で口頭にて確認した . 刺激条件 3 におけ るランダム刺激の刺激間隔は電気刺激装置に連動し た汎用コンピュータ (NEC, PC-98VX)を用いて制 御した。

\section{D. 運動および実験課題}

被験者は，実験用安楽椅子に座り，右前腕を実験 用机の上に置き，肘関節を $160^{\circ}$ に保持した，手関 節および D 1 と D2 の指節間関節は伸展位とし，D1 と D2 間の角度は約 $50^{\circ}$ に保持させ，他の指は屈曲 状態となるようにした．運動課題はFDI の等尺性 筋収縮による D2 の外転運動であった．最初に，被 験者は D2 の外転運動を最大努力で約 5 秒間行っ た。炎の際，得られたFDIの EMG を全波整流し， 最も振幅が大きい2 秒間の EMG 量を EMGmax と して算出した。

被験者は表示されたFDIのEMG 量を目標値 (10\% $\mathrm{EMG} \max )$ にあわせ , 維持するように指示さ れた、被験者にはFDIのEMG 量をアナログ電圧 計(サンワ，AX-313TR)により視覚的にフィードバ ックした。

刺激条件 1 では，D1，D2 および D5 を刺激指と し FDI から導出された皮膚反射を解析した．また， 刺激条件 2 および 3 では, 刺激条件 1 の結果より FDI に対する刺激効果が D2 刺激で最も大きいこと が明らかとなったので，D2 を刺激指として FDI に 誘発された皮膚反射を解析した。

\section{E. データ解析}

皮膚反射の誘発は, $\mathrm{EMG}$ 信号を全波整流し，平 滑化した後, 指皮膚神経への電気刺激をトリガーと して100回の加算平均を行なった(Spike2 version 4, $\mathrm{CED}, \mathrm{UK}$ ，サンプリング周波数 $3 \mathrm{kHz})$. 得られた 皮膚反射は, 先行研究に従( ${ }^{5 \sim 10)}$, 潜時の違い により短潜時抑制 ( I 1 : 頂点潜時：45～60 ms) , 中 潜時促通 (E 2：頂点潜時：60 90 ms)，長潜時抑制 (I2：頂点潜時：90 120 ms), 長潜時促通 (E 3：頂 点潜時：120〜180 ms)の 4 成分に分類した .I 1 ,I 2 ， E 3 の振幅は, 刺激前 $100 \mathrm{~ms}$ の平均背景 $\mathrm{EMG}$ 量 を基準として各反射成分の最大振幅を計測した，従
って ,E 3 は正の值，I 1 と I 2 は負の值で表記した . D 5 刺激により誘発された E 2 は平均背景 $\mathrm{EMG}$ 量 より低いことが確認された(図 1 参照). 光こで, E 2 に関しては I 1 から E 2 の peak-to-peak 振幅を 測定した . 各皮膚反射成分は, 最大随意収縮時に得 られた $\mathrm{EMG}$ を全波整流し，光の平均振幅值で標準 化を行った .

\section{F. 統計処理}

各反射成分の刺激パルス数の違いによる振幅変化 に関しては D 1, D 2 および D 5 刺激を行ったので， 刺激パルス数と刺激指の 2 要因による繰り返しのあ る 2 元配置分散分析 (Repeated two-way ANOVA)を 行い，有意な差が生じた場合には多重比較検定 (Tukey HSD 法)による post-hoc test を行なった . 刺激時間幅および刺激間隔の違いについては, 繰り 返しのある一元配置分散分析 (Repeated one-way ANOVA) 後, 有意な差が生じた場合に多重比較検 定(Tukey HSD 法)による post-hoc test を行なった . データは平均值と標準偏差で示した . 有意水準は危 険率 $5 \%$ 末満とした。

\section{III. 結果}

図 1 は 1 名の被験者より得られたFDI の EMG 記録であり ,D 1(A) ,D 2(B)および D 5(C)を単発(細 線)，2 発(太線)，3 発( 2 点破線)，5発(灰色線) 刺激することにより誘発された皮膚反射の例を示 したものである .いずれの指を刺激した場合でも2 相性の促通効果(E２とＥ３）および抑制効果(I 1 と I 2)が観察された . D 5 刺激における特徵的な点と して，E 2 の最大振幅は背景 EMG レベルより低い 傾向が見られた . D 1 刺激時には, 刺激パルス数の 増大と連動した I 1 と I 2 の振幅が増大し，5発刺 激時には E 2 が減弱した。他指刺激においても，3 もしくは5発刺激時で I 1 と I 2 振幅が増大する傾向 にあった .

図 2 は, 全ての被験者から得られた各皮膚反射成 分の平均振幅(標準偏差)を示したものである. 2 元 配置分散分析の結果, 刺激パルス数の違いによる I 1 振幅の変化は有意であることが明らかになった( F $(3,18)=36.3, \mathrm{p}<0.001)$. 一方，刺激指の違いに よる差は認められなかった $(\mathrm{F}(2,12)=0.775, \mathrm{p}>$ $0.05)$ E E 2 に関しては, 2 元配置分散分析の結果, 


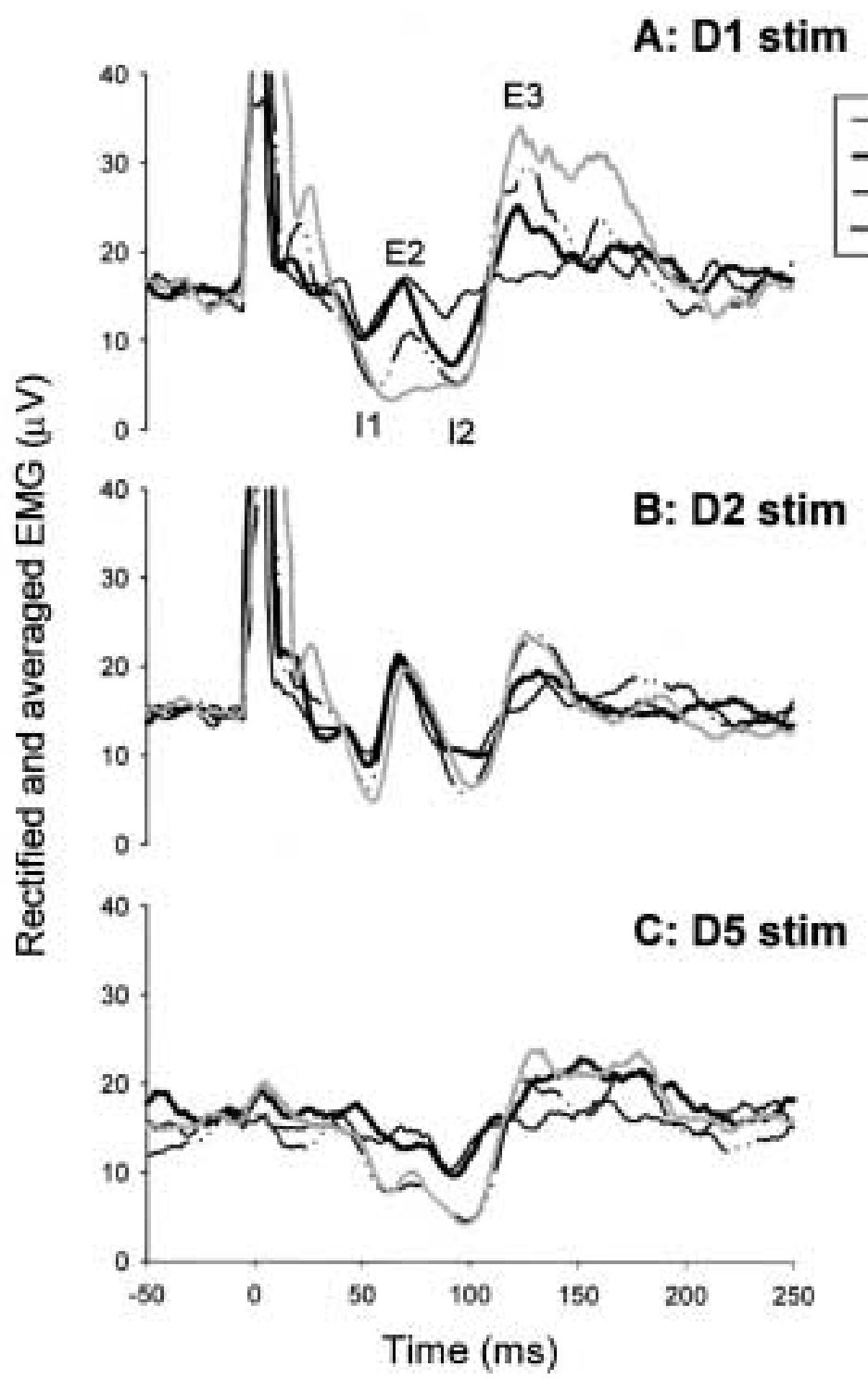

Figure 1. Typical recordings of cutaneous reflexes in FDI following electrical stimulation (2.0 $\mathrm{xPT}$ ) of D1 (A), D2 (B) and D5 (C) obtained from a single subject. In each panel, thick, thin, double dotted and gray lines show the cutaneous reflex elicited by electrical simulation with single, 2, 3 and 5 pulses, respectively. Data were recorded while exerting $10 \%$ of maximal EMG.

パルス数の違いによる有意な変化は見られなかった $(\mathrm{F}(3,18)=1.324, \mathrm{p}>0.05)$. しかし，刺激指の違 いによる有意差が認められた $(\mathrm{F}(2,12)=42.397, \mathrm{p}$ $<0.001)$. Post-hoc test の結果，E2振幅は全ての パルス数で D 1 および D 5 刺激に比して D 2 刺激 時に有意に大きいことが明らかになった(全て $\mathrm{p}<$ 0.01). I 2 に関しては, 2 要因(パルス数, 刺激指) ともに有意な主効果が認められた(パルス数 ; F $(3,18)=24.294, \mathrm{p}<0.001$, 刺激指 $; \mathrm{F}(2,12)=$ 8.994, p<0.01). Post-hoctest の結果, D 1 もし くは D 2 刺激に比して D 5 刺激時に I 2 振幅が有意
に増大していることが明らかになった（2 パルス， D 1 vs. D5, p<0.05, D2 vs. D5, p<0.01；3 パルス , D 2 vs. D5, p <0.05; 5 パルス, D 1 vs. D5, p <0.05, D2 vs. D5, p <0.01). E 3 に関しては, パルス数の 違いによる変化は有意であることが明らかになった が $(\mathrm{F}(3,18)=27.406, \mathrm{p}<0.001)$ ，刺激指には主効 果は認められなかった $(\mathrm{F}(2,12)=2.318, \mathrm{p}>0.05)$. 図 3 は, 全ての被験者から得られた D 2 刺激時 における刺激間隔を変化させたときの FDI の皮膚 反射成分の平均振幅を示したものである．I1 では 刺激間隔の変化による振幅の変化は見られなかった 


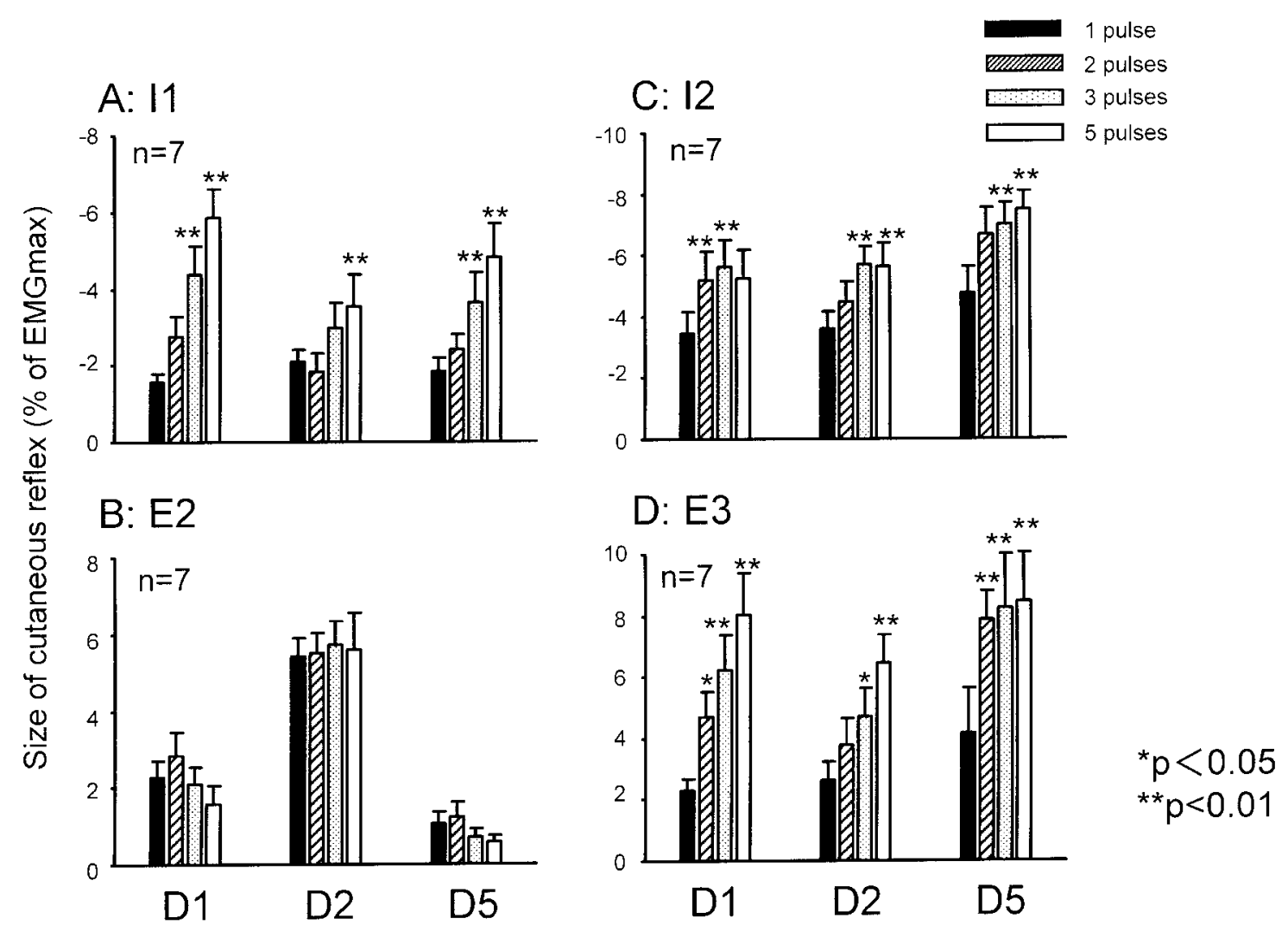

Figure 2. Grand means (and $1 \mathrm{SE}$ ) for I 1 (A), E $2(\mathrm{~B}), \mathrm{I} 2$ (C) and E 3 (D) recorded from FDI elicited by stimulating D1, D2 and D5 with different numbers of pulse trains $(333 \mathrm{~Hz})$. Data are expressed as a percentage of amplitude of the reflex elicited by a single pulse stimulation. Filled, hatched, gray and open bars show the data for single, 2, 3, and 5 pulses, respectively. Asterisks show significant difference from the size of reflexes following a single pulse. ${ }^{*} \mathrm{p}<0.05, * * \mathrm{p}<0.01$.

$(\mathrm{I} 1, \mathrm{~F}(3,18)=0.858, \mathrm{p}>0.05)$. また， E $2, \mathrm{I} 2$ お よび E 3 で刺激間隔が短縮するにつれ，振幅が減少 する傾向が見られ，ランダム刺激( $0.7 \sim 2 \mathrm{~Hz})$ では $3 \mathrm{~Hz}$ の固定刺激時よりも増大する傾向にあったが， いずれの場合も有意差は認められなかった（E2， $\mathrm{F}(3,18)=0.858 ; \mathrm{I} 2, \mathrm{~F}(3,18)=1.686 ; \mathrm{E} 3, \mathrm{~F}(3$, $18)=3.014$, 全て $p>0.05)$.

図 4 は, 全ての被験者から得られた D 2 刺激時 における刺激時間幅を変化させたときの各皮膚反射 成分の平均振幅を示したものであるＩＩ，E２，I2 および E 3 において刺激時間幅に依存した変化は認 められなかった $(\mathrm{I} 1, \mathrm{~F}(2,12)=0.618 ; \mathrm{E} 2, \mathrm{~F}(2,12)$ $=2.856$; I $2, \mathrm{~F}(2,12)=1.211$; E $3, \mathrm{~F}(2,12)=$ 0.4414 , 全て $p>0.05)$.

$$
\text { N. 考察 }
$$

皮膚反射は侵害刺激によって誘発される屈曲反射 とは異なり，低閾值の皮膚感覚受容器および比較的
伝導速度の速い求心性線維によって引き起こされる 反射である ${ }^{3 \sim 13,21,22)}$. 現在までに，上肢および下 肢筋群の皮膚反射は予期せぬ外乱に抗して随意運動 を円滑に継続するために重要な役割を果たしている ことが明らかになっている ${ }^{4,8,14,21,22)}$. しかしな がら，先行研究では，皮膚反射を誘発する電気刺激 のパラメータが必ずしも一致していなかった . 光こ で，本研究ではFDI を対象として皮膚神経刺激の パラメータを操作し, 皮膚反射の変化を観察した。

\section{A. 刺激パルス数に依存した皮膚反射の変化}

皮膚反射は抑制性および興奮性介在ニューロンを 介した多シナプス性反射であることが知られてい $3^{5,24)}$. 電気刺激のパルス数を増大させることは, 皮膚反射経路の標的介在二ューロンに対する時間的 加重を強め ${ }^{12 \sim 14)}$, 結果として反射効果を増大させ ると考えられる.本研究で得られた新たな知見の一 つは, $\mathrm{E} 2$ は他の反射成分と異なり刺激パルス数に 


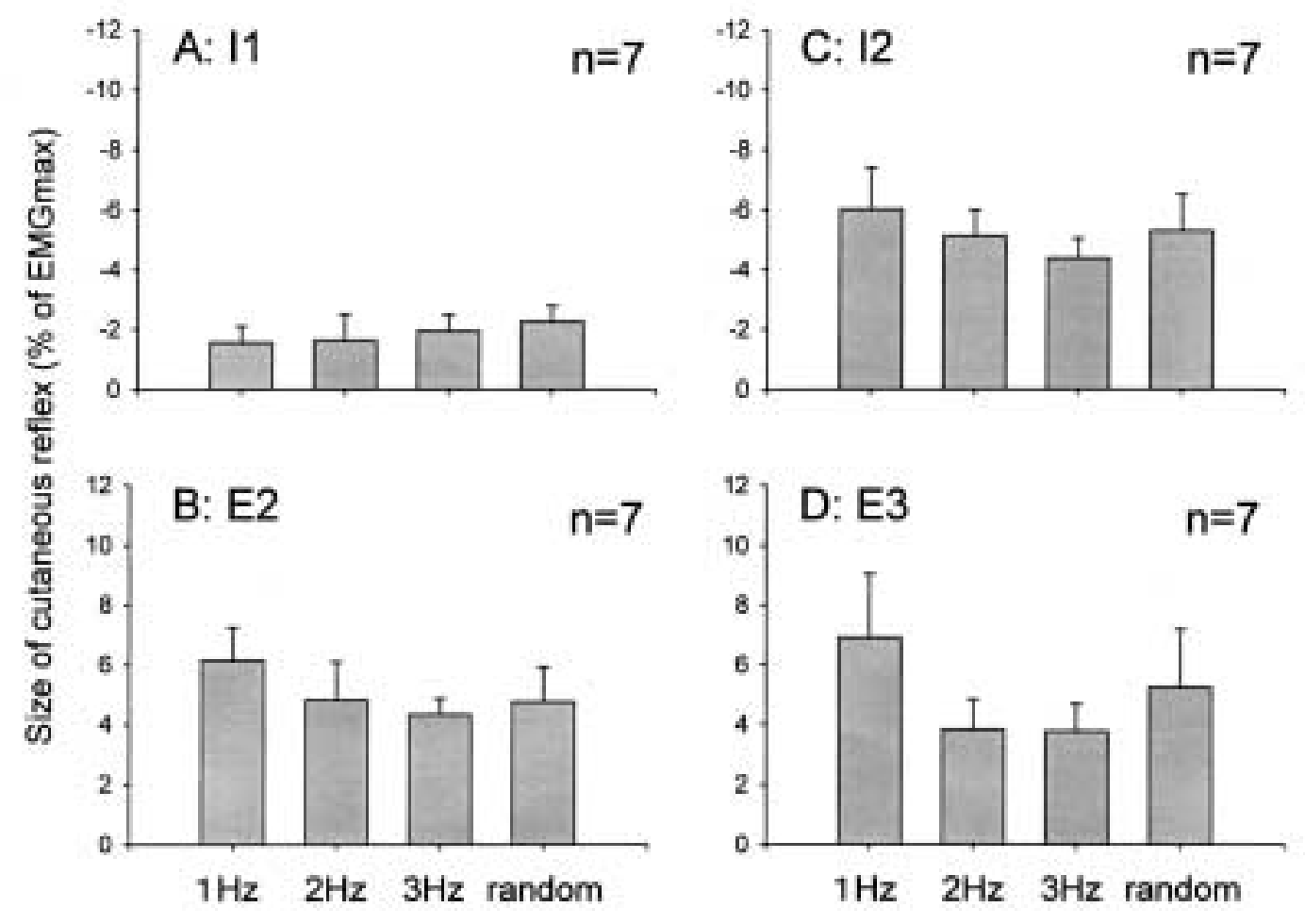

Figure 3. Grand means (and $1 \mathrm{SE}$ ) for I 1 (A), E $2(\mathrm{~B}), \mathrm{I} 2(\mathrm{C})$ and E $3(\mathrm{D})$ recorded from FDI elicited by stimulating D2 $(2.0 \times \mathrm{PT}$, double train pulses : $333 \mathrm{~Hz})$ with different stimulus durations while performing steady D2 abduction at 10\% of EMGmax. All data are expressed as a percentage of the EMGmax.

依存した振幅変化を示さないことである .この結果 は，皮質を含めた $\mathrm{E} 2$ を形成する反射経路に含まれ る介在ニューロン群の一部は，他の皮膚反射経路の 介在ニューロンとは異なり，刺激の時間的加重に応 答しにくい性質を有している可能性を示唆する.

本研究では, E 2 と I 2 振幅は皮膚反射の振幅が 刺激指によって有意に異なることも明らかになった (図 2 参照)。この結果は，E 2 と I 2 は D 1, D 2 お よび D 5 の皮膚求心性線維から FDI 運動ニューロ ンに対する独立した反射経路によって構築されてい る可能性を示唆する ${ }^{14,19,21,23)}$.この考察は, 逆に， I 1 および E 3 は各手指の皮膚求心性線維から FDI 運動ニューロンに対する共通の反射経路の存在を示 唆する.今後，これらの可能性に関してさらに詳細 に検討する必要がある .

本研究では, E 2 以外の反射において刺激パルス 数に依存した変化が大きく，この効果は刺激パルス 数が 3 発以上の時に強いことが明らかになった(図 2 参照). 手固有筋の皮膚反射に関する先行研究で は, 単発刺激を用いた研究が多く $3,5,7 \sim 10)$, さら に I 2, E 3 に関しては報告が少ない12)。また, 単
発刺激によって誘発された I 2 は，不明瞭であるこ とが報告されている゙'). 本研究では連発刺激を用 いることによりI 2 の振幅を増大させ , 安定的に誘 発可能であることが明らかになったが，連発刺激で は侵害受容器を活動させた可能性が残る。しかしな がら，伝導速度の遅い侵害受容器由来の求心性線維 は, 感覚閾值の 5 倍程度から発火してくることが微 小神経電図法を用いた研究から報告されている24). また, 侵害受容器由来の反射効果は非常に強く, 約 50〜100 ms 継続する抑制効果が特徵であるが25)， 本研究で得られた皮膚反射は全て多相性であった . さらに, 本研究では全ての条件で感覚閾値の2倍の 刺激強度を用いていること，ならびに全ての刺激パ ルス数で各被験者に痛みを伴わないことを確認し た . 従って, 刺激パルス数の増大による反射効果の 増大は侵害受容器の活動によるものではないと考え られる.これらのことを考慮すると，I1，I2 およ びE 3 を指標とした実験を行う場合, 痛みが生起し ないことが保証されれば， 3 発以上の連発刺激を用 いることが有効であると考えられる． 


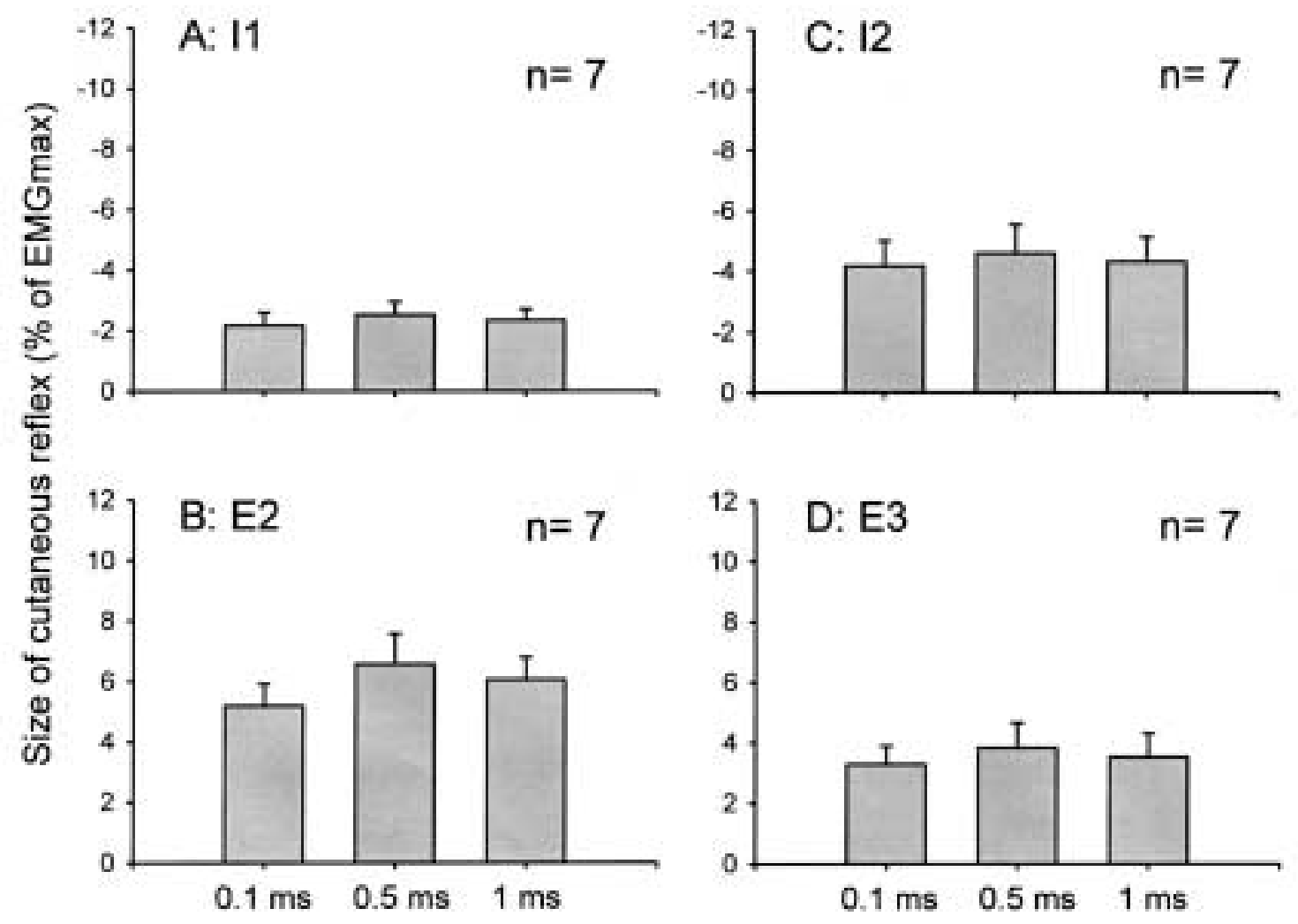

Figure 4. Grand means (and $1 \mathrm{SE}$ ) for I 1 (A), E $2(\mathrm{~B}), \mathrm{I} 2(\mathrm{C})$ and E 3 (D) recorded from FDI elicited by stimulating $\mathrm{D} 2(2.0 \mathrm{xPT}$, double train pulses at $333 \mathrm{~Hz})$ with different stimulus rates while performing steady D2 abduction at $10 \%$ of EMGmax. All data are expressed as a percentage of the EMGmax.

\section{B. 電気刺激の刺激時間幅について} 本研究では, 先行研究の方法に従い, 刺激時間幅 $1 \mathrm{~ms}$ の矩形波による電気刺激を用いた ${ }^{13,14)}$. しか しながら，手指筋を対象とした先行研究では刺激時 間幅 0.1 もしくは $0.2 \mathrm{~ms}$ の電気刺激も用いられて いる ${ }^{7 \sim 11,16,26)}$. 刺激時間幅の違いは, 刺激パルス 数の変化と同樣に属性の異なる皮膚感覚受容器を賦 活させ , 結果として反射効果を変化させる可能性は 否定できない, ${ }^{6,27,28)}$.乥こで, 本研究では, 0.1 , $0.5 お よ ひ ゙ ~ 1 \mathrm{~ms}$ の異なる刺激時間幅を設定して検 討したが各皮膚反射に有意差は観察できなかった . 従って, 刺激強度を同一とした場合(本研究では感 覚閾值の 2 倍)，0.1から $1 \mathrm{~ms}$ 幅の電気刺激で賦活 される皮膚感覚受容器はほぼ同一であると推察する ことが可能であろう. Stephens らのグループは 0.1 $\mathrm{ms}$ 幅の単発刺激により顕著な $\mathrm{E} 1$ と I 1 を報告し ているが7ー10,16)，1 ms 幅刺激や連発刺激ではこ れら反射の出現が不安定となる ${ }^{12 \sim 14,17)}$.この原 因は不明であるが，E１とＩ１ を構成する反射回路 はある限定された求心性線維にのみ応答すること
や，連発刺激による反回抑制やシナプス前抑制の効 果が及んで咸弱する可能性が考えられる ${ }^{5,12)}$.

\section{I 2 および E 3 の機序}

長潜時の皮膚反射の機序については現在まで不明 な点が多い．I 2 に関しては閾值が他の反射効果よ りも低いことが報告されている ${ }^{5,30)}$. I 2 が潜時約 $100 \mathrm{~ms}$ で誘発されることを考慮すると，伝導速度 の速い求心性線維による皮質経由もしくは長潜時脊 髄反射経路の可能性が考えられる ${ }^{31)}$ ）E３(は運動 ニューロンに対するシナプス後抑制に引き続いて起 こるとされる運動単位の同期的発火の可能性が示唆 されていた ${ }^{5)}$. しかし，第2 指電気刺激と経頭蓋的 磁気刺激による運動誘発電位の空間的促通を用いた 実験により皮質経由の反射効果であることが示され ている32)，我々も，FDI による最大随意筋力の $20 \%$ 程度の持続的な張力発揮課題の後半では, I 2 と E 3 は独立して変化することを確認している ${ }^{33)}$. こ れらの報告を考慮すると，刺激パルス数の変化によ る I $2, \mathrm{E} 3$ の修飾は, 脊髄のみならず脳幹や皮質 
レベルで時間的加重が生じている可能性が考えられ る.

\section{D. 刺激間隔の違いよる皮膚反射の変化について} 本研究では皮膚反射には, 刺激間隔の変化(固定 頻度 vs. ランダム)に応じた変化は見られなかった． 刺激間隔の短縮による反射の減弱 (habituation，順 応) (伸張反射，特に長潜時伸張反射で著しいこと が知られている ${ }^{15)}$.この機序の一つとして，伸張 反射では高頻度刺激の際に神経伝達物質の放出量低 減による，いわゆる同名筋抑制が強いことがあげら れる．一方, Harrison et al. ${ }^{16)}$ は，2 から $9 \mathrm{~Hz}$ 頻度 での皮膚反射効果の変化を比較しているが, 顕著な 変化がなかったことを報告している.近年，この反 射順応現象をできるだけ排除するためにランダム刺 激法が用いられ，歩行実験等で応用されている11一 14). 本研究ではランダム刺激 $(0.7 \sim 2 \mathrm{~Hz})$ の検討も 行なったが，E2，I2，E３では $3 \mathrm{~Hz}$ 刺激より若干 増大する傾向にあったが，有意な差は得られなかっ た 、これらの結果を考慮すると，皮膚反射は伸張反 射とは異なり，1 から $3 \mathrm{~Hz}$ 程度までは皮膚反射の 順心は少ない可能性が高い，また，皮膚反射を構成 する神経回路では，伸張反射と異なり刺激間隔の短 縮による伝達物質の放出量の低下が少なく，反射効 果が安定して出現する可能性が考えられる.

感覚閾値の 2 倍程度の電気刺激で誘発される皮膚 反射は, 感覚閾值の 5 倍程度で誘発される侵害受容 器由来の屈曲反射や引つ込み反射とは異なり, 安静 状態では誘発できず，神経束刺激によって誘発する 反射に比して多くの刺激と加算が必要である ${ }^{6,19)}$. 弚のため，試行時間が延長することとなり，疲労等 による影響が少なからずとも含まれることが考えら れる. 本研究で得られた結果を考慮すると，皮膚反 射では $3 \mathrm{~Hz}$ 程度までは刺激間隔を増加させても， “反射の順応現象” は顕著には生じにくいことから， $3 \mathrm{~Hz}$ 刺激を用いることにより実験時間を短縮さ せ，被験者の疲労を軽減することが可能であると考 えられる。

\section{V. 要 約}

1. 健常被験者7名を対象として, 刺激条件，特に 刺激パルス数（1，2，3，5 発)，刺激時間幅 $(0.1,0.5,1 \mathrm{~ms})$ および刺激間隔(固定；1，
$2 ， 3 \mathrm{~Hz}$ ，ランダム；0.7～2 Hz)に着目して 皮膚反射を第一背側骨筋に誘発し, 短( I 1 , ピー ク潜時～45〜60 ms)，中(E2〜60〜90 ms)およ び長潜時(I 2 ， 90〜120 ms ; E3， 120 180 $\mathrm{ms})$ 反射効果の変化を調べた .

2. 2 元配置分散分析の結果, 刺激パルス数の増加 に伴う I 1 ，I 2 および E 3 振幅の増大は有意で あることが明らかになった . (全て $\mathrm{p}<0.001)$. 一方，E２では刺激パルス数に依存した増大は 認められなかった $(\mathrm{p}>0.05)$. また，E２と I2 では刺激指に依存して各皮膚反射成分の変化量 が有意に異なることが明らかになった(両者と もに $\mathrm{p}>0.01)$.

3.I1，E 2，I 2 および E 3 において刺激の持続時 間に依存した変化は認められなかった．また， 刺激間隔や提示方法の違いによる有意な变化も 認められなかった .

4. これらの結果は, 各反射成分を中継する介在二 ユーロンの試験刺激の時間的加重に対する感受 性が異なること，ならびに同一の電気刺激強度 を用いた場合には試験刺激の時間幅が異なって もほぼ同一の皮膚求心性線維を賦活している可 能性を示唆する.

5 . 実践応用として 刺激パルス数 2 から 5 発とし， $3 \mathrm{~Hz}$ の刺激間隔で痛覚をともなわない電気刺 激を用いることにより，筋疲労による潜在的な 影響を低減しつつ，皮膚反射を効率的に誘発す ることが可能と考えられた。

(受理日 平成17年 6 月 21 日)

\section{V. 参 考 文 献}

1) Porter, R. The corticomotorneuronal component of the pyramidal tract: corticomotorneuronal connections and functions in primates. Brain Res. Rev.,(1985), 10 : $1-26$.

2) Wisendanger, M. \& Miles, TS. Ascending pathway of low threshold muscle afferents to the cerebral cortex and its possible role in motor control. Physiol. Rev., (1982), 62, 1234-1261.

3) Evans, A. L., Harrison, L. M., Stephens, JA. Maturation of the cutaneomuscular reflexes recorded from the first dorsal interosseous muscle in man. J. Physiol (Lond).,(1990), $428: 425-40$.

4) Johansson R. S. \& Cole K. J. Grasp stability during manipulative actions. Can. J. Physiol .Pharmacol., (1994), 72, 511-524. 
$5)$ Caccia, M. R., McCormas, A. J., Upton, M. R. M., Blogg, $\mathrm{T}$. Cutaneous reflexes in small muscles of the hand. J. Neurol. Neurosurg. Psychiat.,(1973), 36, 960-977.

6) Deuschl, G. \& Lucking, C. H.. Physiology and clinical applications of hand muscle reflexes. Electroencephalogr. Clin. Neuorophysiol.[suppl].,(1990), 41, 84-101.

7) Jenner J. R \& Stephens J. A. Cutaneous reflex responses and their central nervous pathways studied in man. J. Physiol (Lond).,(1982), 333, 405-419.

8) Evans, A. L., Harrison, L. M., Stephens, J. A. Task dependent changes in cutaneous reflexes recorded from various muscles controlling finger movement in man. J Physiol (Lond).,(1989), 418, 1-12.

9) Nadler, M. A., Harrison, L. M., Stephens, J. A. Acquisition of a new motor skill is accompanied by changes in cutaneomuscular reflex responses recorded from finger muscles in man. Exp. Brain Res.,(2000), 134, 246-254.

10) Garnett, R. \& Stephens, J. A. Changes in the recruitment threshold of motor units produced by cutaneous stimulation in man. J. Physiol (Lond) ., (1980), 303, 351-364.

11) Chen, R. \& Ashby, P. Reflex responses in upper limb muscles to cutaneous stimuli. Can. J. Neurol. Sci., (1993), 20, 271-278.

12) Aniss, A. M., Gandevia, S. C., Burke, D. Reflex responses in active muscles elicited by stimulation of $10 w^{-t h r e s h o l d ~ a f f e r e n t s ~ f r o m ~ t h e ~ h u m a n ~ f o o t . ~ J . ~}$ Neurophysiol.,(1992), 67, 1375-1384.

13) Zehr, E. P., Komiyama, T., Stein, R. B. Cutaneous reflexes during human gait: electromyographic and kinematic responses to electrical stimulation. J. Neurophysiol.,(1997), 77, 3311-3325.

14) Komiyama, T., Zehr, E. P., Stein, R. B. Absence of nerve specificity in human cutaneous reflexes during standing. Exp. Brain Res.,(2000), 133, 267-272.

$15)$ Rothwell, J. C., Day, B. L., Berardelli, A., Marsden, C. D. Habituation and conditioning of the human long latency stretch reflex. Exp. Brain Res., (1986), 63, 197-204.

16) Harrison, L. M., Norton, J. A., Stephens, J. A. Habituation of cutaneomuscular reflexes recorded from first dorsal interossesous and triceps muscle in man. J. Neurol. Sci.,(2000), 177, 32-40.

17) Zehr, E. P. \& Chua, R. Modulation of human cutaneous reflexes during rhythmic cyclical arm movement. Exp. Brain Res.,(2000), 135, 241-250.

18) Hongo, T., Kudo, N., Oguni, E., Yoshida, K. Spatial patterns of reflex evoked by pressure stimulation of the foot pads in cats. J. Physiol (Lond).,(1990), 420, 471-485.

19) Deuschl, G., Feifel, E., Guschlbauer, B., Lucking, C. H.
Hand muscle reflexes following air puff stimulation. Exp. Brain Res.,(1995), 105, 138-146.

20) Zehr, E. P. \& Stein, R. B. What functions do reflexes serve during human locomotion? Prog. Neurobiol., (1999), 58, 185-205.

21) Zehr, E. P. \& Duysens, J. Regulation of arm and leg movement during human locomotion. Neuroscientist, (2004), 10, 347-361.

22) Van Wezel, B. M. H., Ottenhoff, F. A., Duysens, J. Dynamic control of the foot during human walking. J. Neurosci.,(1997), 17, 3804-3814.

23) LaBella, L. A., Kehler, J. P., McCrea, D. A. A differential synaptic input to the motor nuclei of triceps surae from the caudal and lateral cutaneous sural nerves. J. Neurophysiol.,( 1989), 61, 291-301

24) Burke, D., Mackenzie, R. A., Skuse, F., Lethlean, A. K. Cutaneous afferent activity in medial and radial nerve fascicles: a microelectrode study. J. Nueuro. Neurosurg. Psychiat.,(1975), 38, 855-864.

$25)$ Floeter M.K. Cutaneous silent periods. Muscle Nerve., (2003), 28 : 391-401.

26) Datta, A. K. \& Stephens, J. A. The effects of digital nerve stimulation on the firing of motor units in human first dorsal interosseous muscle. J. Physiol (Lond).,(1981), 318, 501-510.

27) McNulty, P. A., Turker, K. S., Macefield, V. G. Evidence for strong synaptic coupling between single tactile afferents and motoneurones supplying the human hand. J. Physiol (Lond).,(1999), 518, 883-893

28) McNulty, P. A. \& Macefield, V. G. Modulation of ongoing EMG by different classes of low threshold mechanoreceptors in the human hand. J. Physiol (Lond).,(2001), 537, 1021-1032.

29) Burke, D., Dickson, H. G., Skuse, N. F. Taskdependent changes in the responses to low-threshold cutaneous afferent volleys in the human lower limb. J. Physiol.(Lond), (1991) $432:$ 445-58.

30) Serrao, M., Parisi, L., Pierelli, F., Rossi P. Cutaneous afferents mediating the cutaneous silent period in the upper limbs: evidences for a role of $10 w^{-t h r e s h o l d ~}$ sensory fibres. Clin. Neurophysiol.,(2001), 112, 20072014.

31) Ghez, C. \& Shinoda, Y. Spinal mechanisms of the functional stretch reflex. Exp Brain Res.,(1978), 32, $55-68$.

32) Ohki, Y., Suzuki, T., Ugawa, Y., Uesaka, Y. Characteristics of excitatory $\mathrm{E} 3$ phase of cutaneous reflexes in the human. Jpn. J. EEG EMG (supp1).,( 1993), 21, 175.

33) 中島 剛, 遠藤隆志, 坂本将基, 小宮山伴与志. 最 大下持続収縮時における皮膚反射および体性感覚誘 発電位 (SEP)の時系列的変動について. 体力科学, $(2003), 6,826$. 